\author{
Łukasz Stankiewicz \\ Uniwersytet Kazimierza Wielkiego w Bydgoszczy \\ E-MAIL: lukasz_stankiewicz@yahoo.com
}

\title{
Polska debata publiczna i odczarowanie akademii - o zmianach w społecznej percepcji uniwersytetu w ostatnich trzech dekadach (CZĘŚć II)
}

\begin{abstract}
STRESZCZENIE
Polski uniwersytet jest w ostatnim czasie przedmiotem wielu publicznych kontrowersji. Dotąd niezakończona publiczna debata wokół reformy systemu szkolnictwa wyższego i nauki z roku 2011 zmienia sposób, w jaki zarówno akademicy, jak i inne grupy społeczne, myślą i mówią o uniwersytecie. Celem tego artykułu będzie podsumowanie badań własnych dotyczących obecności, w ostatnich trzech dekadach, krytycznych wobec akademii dyskursów w mediach masowych oraz próba ich interpretacji za pomocą instytucjonalnej teorii organizacji. Obecna sytuacja uniwersytetu jest uznawana za przejaw kryzysu legitymizacji, towarzyszącego blisko ze sobą powiązanym zmianom w zakresie demografii, struktury finansowania, stosunków pomiędzy akademią i państwem i wewnętrznych stosunków pomiędzy aktorami operującymi w sektorze. Sumarycznym efektem tych zmian jest przejście uniwersytetu z obszaru organizacji opartych na autorytecie, do obszaru organizacji technicznych - operujących w oparciu o racjonalną kalkulację dotyczącą przydatności ich produktów i usług. Zmiana ta, chociaż pozostaje w sprzeczności $\mathrm{z}$ humanistycznym dyskursem na temat uniwersytetu, posiada wiele historycznych precedensów i jest wyrazem rosnącego znaczenia działalności akademickiej, zarówno w jej wymiarze edukacyjnym, jak i wiedzotwórczym.
\end{abstract}

SŁOWA KLUCzOWE: szkolnictwo wyższe, dyskurs, debata publiczna.

Celem niniejszego artykułu jest, posiłkująca się historycznymi i teoretycznymi analizami, rekonstrukcja trwającej od 2008 roku debaty nad przyszłością polskiego szkolnictwa wyższego jako procesu zawiązywania umowy społecznej pomiędzy akademią a nowymi (z polskiej perspektywy) siłami społecznymi - liberalnym państwem i klasą średnią.

Pierwsza część artykułu (opublikowana w obecnym numerze „Parezji”) dotyczyła historii powiązań świata akademickiego z jego społecznym otoczeniem. Uniwersytety, od samych swoich początków, pełniły rolę pedagogicznego i ideologicznego zaplecza dla sił społecznych, oferujących im prawną ochronę i zabezpieczających materialne warunki ich trwania. Wypełnianie akademickich misji - tworzenia lub przekazywania wiedzy i szkolenia jej 
przyszłych twórców - zawsze było zależne od negocjacji z aktorami społecznymi, konsumującymi niektóre $\mathrm{z}$ wytwarzanych czy świadczonych $\mathrm{w}$ akademii dóbr i usług, od szkolenia dostojników kościelnych poczynając, na budowie potężnej broni kończąc.

Poczynając od wieku XX, uniwersytety, oparte na dominującym od poprzedniego stulecia modelu humboldtowskim, zaczęły uzyskiwać coraz większy wpływ na sprawy społeczne. Wytwarzane w nich dobra stały się kluczowe zarówno dla konsumującego wiedzę lub wspierającego konsumującą ją gospodarkę państwa, jak i objętej nieformalnym przymusem edukacyjnym dotyczącym wykształcenia wyższego klasy średniej. Niestety, wraz ze wzrostem wpływu (i większą kapitałochłonnością) wzrasta również presja regulacyjna wywierana na akademię przez jej klientów. Uniwersytety, jako „równe swoją wagą przemysłowi ciężkiemu”, nie mogą być już traktowane jako „pomniejsze przedsięwzięcie zarządzane przez intelektualną elitę” (Graham, 1998, za: Etzkowitz, Webster, Gebhardt i Terra, 2000, s. 329). Próby zewnętrznej regulacji akademickiej pracy lub dążenie do jej urynkowienia, choć są konsekwencją obiektywnego sukcesu akademii, stawiają w wątpliwość możliwość kontynuacji jej autonomicznych misji.

W Polsce negocjacja pomiędzy liberalnym państwem, klasą średnią i akademią rozpoczęła się niespełna dekadę temu, przy okazji debaty nad reformą systemu szkolnictwa wyższego i nauki przeprowadzonej przez rząd Platformy Obywatelskiej i Polskiego Stronnictwa Ludowego. Tę próbę zarysowania nowej „umowy społecznej” pomiędzy polską akademią i jej publicznościami poprzedzało stulecie, w którym, pomimo okresowego nacisku quasi-autorytarnych, autorytarnych czy totalitarnych rządów, uniwersytet był w stanie zachować względną niezależność. Siła polskiej akademii przed transformacją ustrojową wiązała się z dużym znaczeniem inteligencji, specyficznej dla Europy Środkowo-Wschodniej klasy, legitymizującej swoją pozycję społeczną uzyskanym kapitałem kulturowym (w przeciwieństwie do tradycyjnej burżuazji, która opiera ją na kapitale ekonomicznym, czy arystokracji lub rządów partyjnych, gdzie władzę dzierżą posiadacze zinstytucjonalizowanego kapitału społecznego). Wpływy inteligencji dawały instytucjom edukacji wyższej, stanowiącym źródło zinstytucjonalizowanego kapitału kulturowego, dużą odporność na ingerencję wich autonomiczne struktury. Zarówno to, jak i uwarunkowania specyficzne dla społeczeństwa socjalistycznego (np. niska premia płacowa $\mathrm{z}$ tytułu posiadania wykształcenia wyższego), sprawiły, że aż do roku 1989 akademia zachowała elitarną naturę - zapewniając inteligencji niezbędną dla jej trwania ekskluzywność wykształcenia wyższego. 
Opisana powyżej sytuacja zmieniła się, gdy klasa wykształcona pokonała ostatniego ze swoich, zarządzających krajem w oparciu o zinstytucjonalizowany kapitał społeczny, przeciwników - partię komunistyczną. W wyniku transformacji ustrojowej inteligencja i (w konsekwencji) uniwersytety stanęły wobec nowych sił społecznych, najważniejszą z których jest klasa średnia.

\section{Konsekwencje transformacji ustrojowej}

Klasa średnia - rozumiana jako warstwa, której istnienie opiera się na posiadaniu kapitału ekonomicznego - nie ma długiej historii. W Europie powstała ona po II wojnie światowej, gdy długotrwała inflacja doprowadziła do, wieszczonej wcześniej przez Keynesa, „eutanazji rentierów” (Keynes, 2003), a powojenny cud gospodarczy pozwolił na akumulację kapitału mniej więcej połowie z grupy, która we wcześniejszym (cechującym się znacznie wyższym poziomem nierówności) reżimie należała do dysponującej zaledwie dziesięcioma procentami kapitału dziewięćdziesięcioprocentowej większości społeczeństwa (Piketty, 2014). Celem klasy średniej nie jest akumulacja kapitału kulturowego, tylko ekonomicznego, a jednym z narzędzi w pogoni za tym ostatnim jest wykształcenie - traktowane nie jako cel sam w sobie i podstawowa matryca generująca podziały społeczne, ale środek do celu, jakim jest uzyskanie wysokiej pozycji na rynku pracy najemnej.

Powojenne programy mające wspomóc weteranów w Stanach Zjednoczonych (Cohen i Kisker, 2010) i późniejsza reakcja, stale dążących do nadgonienia amerykańskiej przewagi w nauce i nauczaniu państw europejskich, uruchomiły proces, dzięki któremu wykształcenie wyższe z dobra zdobywanego głównie przez przedstawicieli klas wyższych, stało się powszechnie dostępne. Proces umasowienia w Polsce rozpoczął się dopiero po roku 1989. Przez cały okres komunistyczny uniwersytety, pomimo wielokrotnego wzrostu naboru w stosunku do okresu przedwojennego, zachowały swój elitarny i w przeważającej mierze inteligencki charakter (Borowicz, 1983). Potransformacyjne umasowienie było wynikiem oddziaływania trzech czynników: liberalizacji prawa, dzięki której możliwe stało się tworzenie szkół niepublicznych (których działalność, aż do powstania Państwowej Komisji Akredytacyjnej w 2002 roku, nie była przedmiotem znaczących regulacji); potransformacyjnej polityki oszczędności, w wyniku której gwałtownie spadły publiczne nakłady na naukę i nauczanie; wreszcie - gwałtownego wzrostu popytu na dyplomy szkół wyższych, będącego efektem pojawienia się nieznanych w komunizmie zjawisk: bezrobocia i znacznej premii płacowej z tytułu posiadanego wykształcenia (Stankiewicz, 2015b). 
Pozbawione środków do dalszego funkcjonowania w wyniku cięć budżetowych i, jednocześnie, dzięki liberalnej polityce państwa i pojawieniu się popytu na ich usługi, mogące prowadzić zyskowną działalność komercyjną, szkoły wyższe zaangażowały się w sprzedaż usług edukacyjnych. W efekcie liczba studentów zwiększyła się - pomiędzy 1989 a 2005 rokiem - blisko pięciokrotnie, osiągając poziom niespełna 2 milionów. W połowie drugiej dekady po transformacji ponad połowa studiujących płaciła za swoje wykształcenie, a większość studiowała na niewymagających (zarówno z perspektywy studentów, jak i szkół, które nie musiały przeznaczać znacznych środków na ich uruchomienie) kierunkach z zakresu humanistyki, nauk społecznych, prawa, marketingu i zarządzania (Borowiec, 2011). Dopływ pieniędzy z czesnego, poza umożliwieniem przetrwania systemu publicznej edukacji wyższej, przyczynił się do powstania rozległej sieci szkół niepublicznych (liczącej, u szczytu demograficznego wyżu, ponad 300 placówek). Państwo, finansujące edukację i naukę w bardzo ograniczonym zakresie (Hejnicka-Bezwińska, 2011), na okres ponad dekady wycofało się z jakichkolwiek prób regulowania systemu (Kwiek, 2009).

Finansowe problemy uniwersytetu i wynikające $\mathrm{z}$ nich umasowienie pozbawiło akademików pozycji strażników dostępu (gatekeepers) do społeczności szczycącej się posiadaniem, będących świadectwem zdobycia „kulturowego szlachectwa", dyplomów. Co prawda, choć:

całkowita liczba miejsc w sektorze publicznym w latach 1990-2007 zwiększyła się o 225\% (z 400000 w 1990 do 1300000 w 2007), o tyle całkowita liczba miejsc najcenniejszych, czyli miejsc w systemie bezpłatnym zwiększyła się tylko o 165\% (z około 300000 do około 800000). Na trzech najlepszych polskich uniwersytetach (UW, UJ i UAM) całkowita liczba studentów studiów dziennych, zwłaszcza magisterskich, zwiększyła się w tym samym czasie o nie więcej niż $100 \%$ (...). Opłaty za studia jako nowe źródło finansowania sektora publicznego istotnie zmieniły skład społeczny polskich studentów, ale zarazem najlepsze polskie uczelnie, (...) nie dopuszczały do radykalnego pogarszania się jakości kształcenia w przypadku swoich tradycyjnych (również tradycyjnych w sensie pochodzenia społeczno-ekonomicznego) studentów dziennych (Kwiek, 2010, s. 300-301).

Tym staraniom, mającym na celu zachowanie pewnej ekskluzywności wykształcenia, przeciwdziałały dwa czynniki. Po pierwsze - poza kwestią podziału na studia płatne i bezpłatne rynek edukacyjny nie był, przez samych jego klientów, dobrze rozpoznany (Kwiek, 2013). Studia różnicowały się jakością - od najstarszych szkół, starających się utrzymywać wysoki poziom nauczania, po „sprzedające” dyplomy prowincjonalne szkoły niepubliczne, ale świadomość istnienia tych różnic $\mathrm{i}-\mathrm{w}$ konsekwencji - rozziew w prestiżu uzyskiwanych kredencjałów był nieznaczny. Tym, co kierowało edukacyjnymi wybo- 


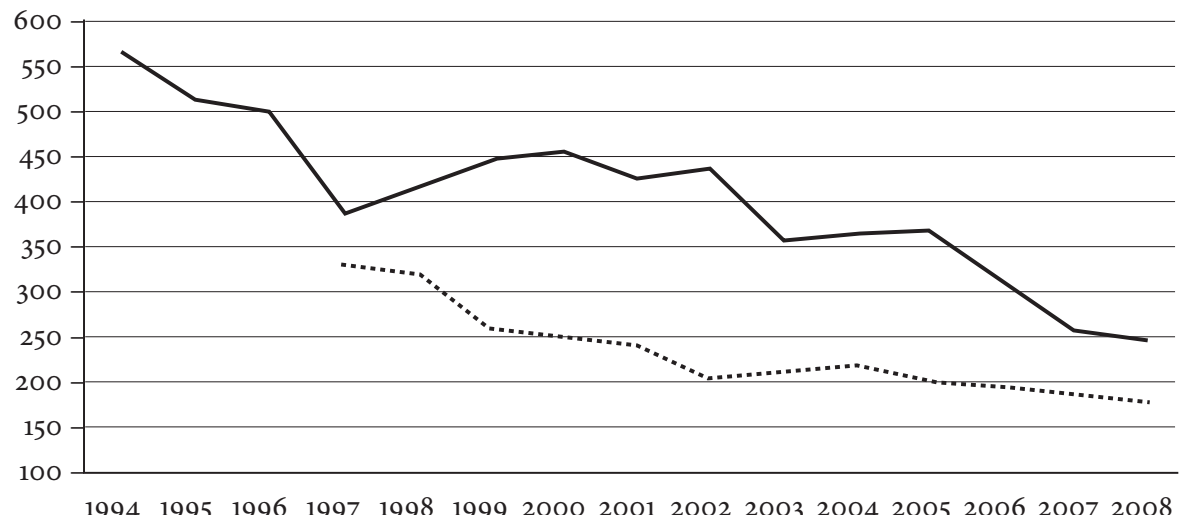

— Dochód $\quad$ …... Zawód

Wykr. 1. Procentowa przewaga w poziomie skolaryzacji III stopnia u osób z rodzin należących do I kwintyla dochodu (najbogatszych) wobec osób należących do V kwintyla (kategoria: dochód) i osób z ojcem posiadającym wyższe wykształcenie wobec osób, których ojciec jest robotnikiem niewykwalifikowanym (kategoria: zawód)

Źródło: Herbst i Rok, 2011; opracowanie własne.

rami, była więc raczej geograficzna dostępność niż jakość studiów. Nie doszło do wytworzenia się ogólnopolskiego rynku edukacyjnego właściwego krajom, w których istnieją sektory elitarne (Karabel, 2005). Po drugie, chociaż we wczesnej fazie umasowienia wykształcenie zdobywały głównie osoby należące do grona „tradycyjnych” klientów akademii - czyli osoby z rodzin zamożnych lub wykształconych - o tyle z upływem czasu ich dominacja w szkołach wyższych, jakkolwiek nadal wyraźna, zaczęła się zmniejszać (patrz: wykr. 1).

Zmiana ta oznaczała, że edukacja wyższa straciła zarówno cechę bycia dobrem rzadkim, jak i swoją klasową ekskluzywność, czego konsekwencją była stopniowa inflacja wartości dyplomów.

Inflacja dyplomów i związany z pogorszeniem warunków nauczania (mniejszymi nakładami na studenta i pogorszeniem proporcji wykładowców do studentów) spadek jego jakości, to dwa z potencjalnie zmniejszającymi społeczny autorytet akademii efektów umasowienia. Trzecim była, związana $\mathrm{z}$ „dryfem dydaktycznym", czyli warunkowaną czynnikami finansowymi niezdolnością nawet najlepszych uniwersytetów do ograniczenia naboru (Stankiewicz, 2016b), przewaga działalności dydaktycznej nad badawczą. Efekt ten dotyczył w szczególnym stopniu dyscyplin humanistycznych i społecznych, na których opierał się sektor szkół niepublicznych. W połączeniu z drastycznym spadkiem nakła- 
dów na naukę (z o,8\% PKB w 1991 r. do o,3\% PKB w 2005 r., Wolszczak-Derlacz i Parteka, 2010) przyczyniło się to do znacznego zmniejszenia produktywności naukowej polskich akademików (Kwiek, 2012, 2015).

Pomimo tego, zakorzeniony społecznie autorytet akademii, a także uznawane początkowo za sukces umasowienie i wynikająca $z$ niego relatywna finansowa niezależność szkół wyższych - osłoniły ją, w okresie pierwszej potransformacyjnej dekady, przed społeczną krytyką. Dopiero po roku 2000 opinia publiczna, a w szczególności media masowe zaczęły zauważać pewne niedoskonałości istniejącego systemu. Ich, umiarkowana z początku, krytyka z czasem przerodziła się w całkowitą negację i, tym samym, kryzys legitymizacji polskiej akademii.

\section{Kryzys legitymizacji}

Gra pomiędzy organizacjami i ich otoczeniem społecznym, mająca na celu uzyskanie przez te pierwsze legitymizacji (i w konsekwencji środków niezbędnych do zabezpieczenia swojego trwania), rozgrywa się współcześnie głównie w przestrzeni mediów masowych i języka (Meyer i Rowan, 1977; Suchman, 1995; Jessop, 2002). Organizacje uzyskują legitymizację, jeśli są w stanie wyjaśnić swoją działalność w sposób zrozumiały dla ich publiczności i jednocześnie tak, by wydawała się ona zgodna z prawem i obyczajem, racjonalna, pożyteczna dla ogółu i godna dalszego wsparcia. By uzyskać ten efekt, komunikujące się ze swoim otoczeniem organizacje preferują konwencjonalne, przewidywalne formy autoprezentacji (Ashforth i Gibbs, 1990; Deephouse, 1996). Pojawienie się medialnej krytyki jest więc przejawem tarć pomiędzy organizacją i jej otoczeniem. Kryzys legitymizacji to okres nasilonej i długotrwałej krytyki, w reakcji na którą organizacja musi uciekać się do takich strategii, jak zaprzeczanie, wymówki, wyjaśnienia, uzasadnienia czy strategiczne restrukturyzacje (Suchman, 1995). W ramach najpoważniejszych kryzysów, gdy niedobór społecznej legitymizacji przeradza się w rzeczywisty kryzys instytucji, podważane są nie tyle któreś z przejawów działania organizacji, ale sam jej związek z utrzymującymi ją publicznościami (Stankiewicz, 2016a).

Ta ostatnia, najostrzejsza forma kryzysu występuje wtedy, gdy pod wpływem zmian, jakie nastąpiły w samej organizacji czy oczekiwaniach jej publiczności, istniejące języki przestają wystarczać do opisu i uchwycenia logiki sytuacji społecznej. Konieczne jest jednoczesne wytworzenie nowej wiedzy i nowych dyskursów, jak i dogłębna restrukturyzacja powiązań łączących obie strony. Metodą wykorzystywaną przez demokratyczne społeczeństwa, muszące poradzić sobie z takimi sytuacjami, są szerokie debaty społeczne (Jessop, 2002). 
Większość opisanych powyżej procesów znajduje szeroki oddźwięk lub wręcz rozgrywa się w mediach masowych. Powoduje to, że relatywnie łatwe jest ich śledzenie. Obserwacja zwiększania się ilości artykułów, wykraczających poza konwencjonalne wzorce codziennej legitymizacji, może pozwolić nam ustalić momenty występowania kryzysów społecznego zaufania (Stankiewicz, 2015a, 2016a). W ten sposób badanie obecności krytycznych wypowiedzi dotyczących systemu szkolnictwa wyższego i nauki w mediach masowych umożliwia nam ocenę stopnia napięcia pomiędzy polskim uniwersytetem i jego społecznym otoczeniem.

Niniejszy artykuł podsumowuje trzy (zbliżone do siebie pod względem przyjętej metodologii) projekty badawcze. Empiryczną bazą dla analizy kryzysów legitymizacji polskiego uniwersytetu były materiały z „Gazety Wyborczej” i jej wydań lokalnych, z lat 1989-2014 (Stankiewicz, 2015a). Wnioski dotyczące ostatniego, i najpoważniejszego z epizodów kryzysowych, są też oparte na analizie dyskursu dwóch największych tygodników („Polityka” i w zależności od roku: „Wprost”, „Newsweek”, „W Sieci”) i dzienników („Gazeta Wyborcza” i „Rzeczpospolita”) z lat 2007-2014, a także na analizie pozaprasowych publikacji związanych z debatą z lat 2007-20101. Głównym metodologicznym punktem odniesienia była Krytyczna Analiza Dyskursu Normana Fairclough’a (KAD), (Fairclough, 2001; Duszak, Fairclough, 2002). Wykorzystanie KAD pozwoliło na analizę tego, w jaki sposób autorzy publicznych wypowiedzi konstruują dyskursywne „reżimy” pozwalające im na intelektualne rozpoznanie wybranych fragmentów społecznej rzeczywistości, dominujących w nich interakcji i form podmiotowości. Ten proces dyskursywnego „splatania tego, co społeczne" (Latour, 2010) pozwala aktorom na podjęcie w polach społecznych działań, mających na celu realizację interesów własnych (Jessop, 2002). W połączeniu z ramą interpretacyjną, na którą składały się przybliżone w pierwszej części artykułu: instytucjonalna teoria organizacji, teoria legitymizacji i teoria Bourdieu, a także historycznymi rekonstrukcjami endemicznych dla akademii form konfliktu społecznego i kierunku współczesnych transformacji uniwersytetu, opisana tu metodologia pozwoliła mi na sformułowanie "gęstej” teoretycznie, ale jednocześnie skoncentrowanej na poszczególnych aktorach i ich działaniach rekonstrukcji debaty i jej uwarunkowań.

Baza materiałów z lat 2007-2010 została stworzona na potrzeby projektu doktorskiego pt: Wizje uniwersytetu w polskiej debacie publicznej 2007-2009, napisanej pod przewodnictwem prof. dr. hab. Tomasza Szkudlarka i obronionej w lutym 2014 na Uniwersytecie Gdańskim (Stankiewicz, 2016). Materiały z lat 2011-2014 zostały zgromadzone na potrzeby projektu „Urządzanie uniwersytetu”, prowadzonego przez dr hab. Helenę Ostrowicką z Uniwersytetu Kazimierza Wielkiego w Bydgoszczy (http://dyskurs.ukw.edu.pl/). 


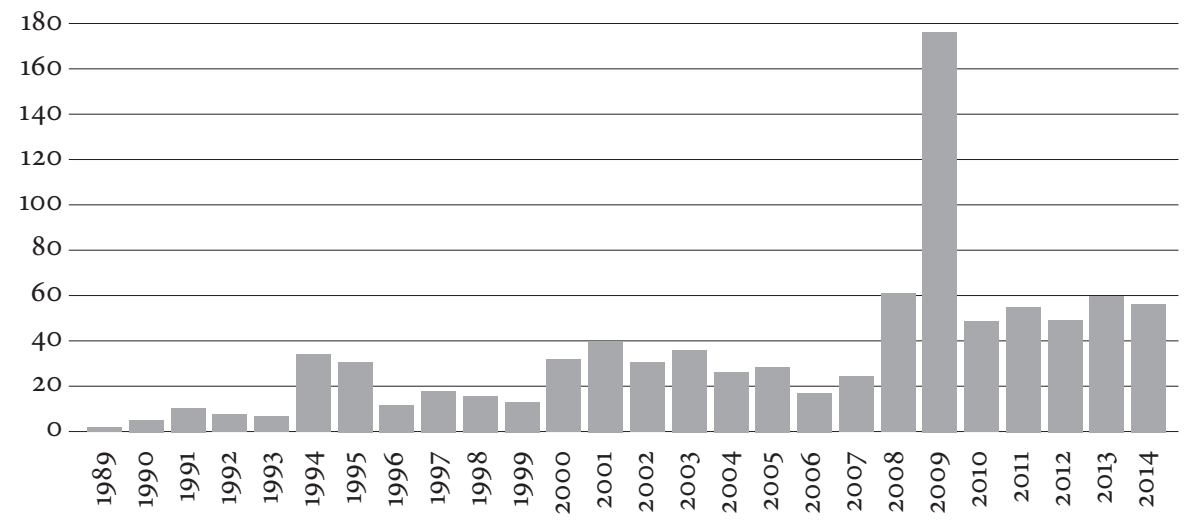

Wykr. 2. Krytyczne artykuły na temat systemu szkolnictwa wyższego i nauki w Polsce w „Gazecie Wyborczej” i jej wydaniach lokalnych

Źródło: Stankiewicz, 2015a

Z ilościowej analizy artykułów medialnych można wywnioskować, że pomiędzy rokiem 1989 a 2014 miały miejsce 3 epizody kryzysowe (patrz: wykr. 2): pierwszy, obejmujący lata 1994-1995, wiązał się głównie z krytyką systemu szkolnictwa wyższego i nauki dokonywaną z perspektywy samej akademii, której pracownicy zwracali uwagę opinii publicznej na negatywne konsekwencje polityki oszczędności w odniesieniu do uczelni. Jednym z efektów tej krytyki było (tymczasowe, zakończone wraz ze spowolnieniem gospodarczym roku 2000) wyhamowanie dynamiki spadku nakładów na naukę i pewien wzrost publicznych środków przeznaczanych na dydaktykę akademicką (Wolszczak-Derlacz i Parteka, 2010; Geryk, 2007). Drugi epizod kryzysowy, w latach 2000-2003, przejawiał się we wzroście ilości doniesień medialnych na temat niskiej jakości nauczania w szkołach niepublicznych i wieloetatowości akademików. Jego konsekwencjami było powołanie Państwowej Komisji Akredytacyjnej i wprowadzenie (jak się później okazało, zbyt słabych) regulacji dotyczących wieloetatowości w ramach reformy szkół wyższych z roku 2005. Ostatni, najpoważniejszy i nadal niezakończony, kryzys legitymizacji akademii rozpoczął się w roku 2008. Czynnikiem wyzwalającym społeczną debatę były pierwsze doniesienia dotyczące planowanego kształtu reformy minister Barbary Kudryckiej. Dążenie do reformowania uniwersytetu wynikło z nadchodzącego niżu demograficznego, który w latach 2005-2020 miał doprowadzić do spadku liczebności dziewiętnastolatków o 41\% (z 6,1 do 3,6 miliona, Antonowicz i Godlewski, 2011). Ponieważ dochód szkół publicznych był uzupełniany przez pochodzący z czesnego kapitał prywatny, a dochód uczelni niepublicznych jest całkowicie od tego kapitału zależny, więc niż sta- 
nowił bezpośrednie zagrożenie dla całego, przystosowanego raczej do szybkiego wzrostu niż kontrakcji, systemu. Dyskusja wokół reformy Kurdyckiej nie dotyczyła jednak wyłącznie (ani nawet w stopniu dominującym) konsekwencji zmian demograficznych. Sposób, w jaki się rozpoczęła - od humanistycznej krytyki rządowych planów likwidacji habilitacji - wyznaczył wzorzec późniejszej debaty, angażującej wszystkich interesariuszy i wszystkie (z wyłączeniem administracji) kategorie pracowników akademii w ostry spór polityczny, dotyczący jej przyszłości (Stankiewicz, 2016a).

W ciągu ostatniej dekady konflikt ten dogłębnie zmienił zarówno społeczną świadomość dotyczącą akademii, jak i język, którym się o niej mówi, przyczyniając się też do rzeczywistej zmiany sytuacji zawodowej pracowników uniwersytetów.

Dyskursywny szok, jakiego doznała zarówno akademia, jak i jej społeczne otoczenie w pierwszych latach debaty wynikł z odkrycia przez jedną i drugą stronę nieadekwatności języków, jakimi posługiwały się one w swoich próbach opisu sytuacji uniwersytetu. System szkolnictwa wyższego i nauki, który w roku rozpoczęcia sporu był już bytem społecznym całkowicie odmiennym od elitarnych i dobrze finansowanych akademii i instytutów czasów komunistycznych, był, aż do kryzysowej korekty, nadal opisywany językiem wytworzonym do opisu tych ostatnich. Zarówno poziom nauczania (w uczelniach publicznych), jak i nauki, był w pochodzących sprzed 2008 roku doniesieniach prasowych uznawany za porównywalny z zachodnim (Stankiewicz, 2015a). Dopiero ciągnący się całą dekadę spór o uniwersytet pozwolił na zasypanie „dyskursywnej luki”, jaka oddzielała słowa od rzeczy - w niektórych wypadkach przyczyniając się zresztą do powstania nowych, stojących w sprzeczności $\mathrm{z}$ dostępną empirycznie rzeczywistością, mitów. To z publikacji związanych z tą debatą społeczeństwo polskie po raz pierwszy dowiedziało się o inflacji wartości dyplomów, jak również - w postaci doniesień o wynikach konkurencji o granty europejskie czy niskiej pozycji polskich uniwersytetów w światowych rankingach - o rzeczywistych konsekwencjach niedofinansowania nauki.

Sam proces debaty był daleki od ideału racjonalnej wymiany zdań (Stankiewicz, 2016a). Opierał się on (i nadal opiera) na anegdotycznych doniesieniach, „ludowych teoriach” (folk theories), całkowicie ignorujących dostępne dane empiryczne, wreszcie - i przede wszystkim - na artykulacjach silnie powiązanych z interesem własnym, biorących w niej udział aktorów społecznych.

Celem kolejnej sekcji jest próba podsumowania roszczeń głównych aktorów sporu i, tym samym, wyjaśnienia przyczyn i możliwych rozwiązań kryzysu legitymizacji polskiego uniwersytetu. 


\section{Uwarunkowania kryzysu}

W wyniku zmian towarzyszących transformacji polska struktura gospodarcza i społeczna - włączając w to sposób działania uniwersytetów - zbliżyła się do struktur krajów zachodnich. Dla akademii zmiana ta oznacza konieczność ułożenia się z nowymi publicznościami: liberalnym państwem, finansowa zależność od którego będzie z upływem czasu rosła z powodu wysychania źródeł kapitału prywatnego, i klasą średnią, liczącą na zwrot ze swoich inwestycji prywatnych i na racjonalność w wydatkowaniu funduszy publicznych. Dominacji tych dwóch podmiotów społecznych towarzyszy kres starego reżimu, w którym posiadanie lub nieposiadanie wykształcenia było jednym z podstawowych zasad społecznego podziału - ściśle wiążąc interesy jednej z dominujących klas społecznych z interesami akademii - i w którym państwo było w swoich działaniach ograniczone albo przez autorytet instytucji szkolnictwa wyższego albo przez własną, wynikającą z politycznej niestabilności, słabość.

Negocjacja z nowymi siłami społecznymi nie jest łatwa czy jednotorowa - również dlatego, że akademia nie mówi jednym głosem. W czasie trwania debaty roszczeń wobec systemu szkolnictwa wyższego nie wyrażali tylko jego interesariusze, ale również sami akademicy - od szeregowych pracowników poczynając, na rektorach kończąc. Specyficzna struktura akademii, fakt, że jest ona uznawana raczej za wspólnotę niż miejsce pracy, i to, że jej pracownicy są obdarzeni wysokim statusem społecznym, pozwolił na branie udziału w debacie grupom, które - gdyby podobna dyskusja dotyczyła organizacji silniej zhierarchizowanych - musiałyby pozostać nieme.

Ten napływający $\mathrm{z}$ uniwersytetu wielogłos uniemożliwił reprezentantom środowiska - rektorom zgromadzonym w Konferencji Rektorów Akademickich Szkół Polskich (KRASP) - na przedstawienie spójnego stanowiska wobec napływającej z wielu kierunków krytyki akademii (Stankiewicz, 2016a). Oznacza to, że nie należy wciąż trwającej debaty rozumieć wyłącznie jako buntu konsumentów wytwarzanych przez akademię dóbr czy usług, ale również rodzaj insurekcji pracowników niższego szczebla, szczególnie w latach 2008-2010 zapełniających szpalty gazet wszechstronną krytyka istniejącego systemu (Stankiewicz, 2016a).

Główne role w debacie odgrywają jednak dwie nowe grupy interesariuszy.

Państwo, osłabione transformacją i przez długi czas skłonne raczej unikać obowiązków, przerzucając je na rynek czy samorządy, niż brać odpowiedzialność za nowe sfery życia społecznego, uległo w ciągu ostatnich dwóch dekad znacznemu wzmocnieniu. Podobnie jak w okresie międzywojennym - gdzie we wczesnych latach po odzyskaniu niepodległości zakres akademickiej autonomii był szeroki, ale stopniowo ograniczano go wraz ze wzrostem asertyw- 


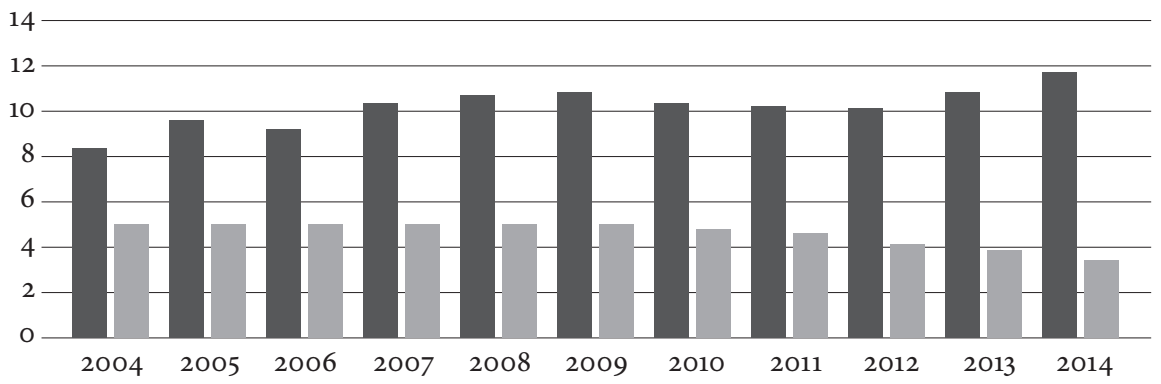

Wykr. 3. Publiczne i prywatne nakłady na edukację wyższą (w miliardach złotych z 2015 roku)

Źródło: Stankiewicz, 2015a

ności aparatu państwowego (Antonowicz, 2015) - samo okrzepnięcie państwa, niemuszącego już radzić sobie z chaosem transformacji, sprzyja ponownemu przejęciu przez nie kontroli nad systemem szkolnictwa wyższego (Kobylarek, 2013).

Drugim, zwiększającym siłę państwa czynnikiem, jest niepewna sytuacja finansowa uniwersytetów. Związany z niżem ubytek kapitału prywatnego został przez ministerstwo uzupełniony z budżetu (patrz: wykr. 3). Daje to rządowi znaczną przewagę $\mathrm{w}$ negocjacjach $\mathrm{z}$ coraz silniej od niego zależnymi szkołami wyższymi i jednocześnie motywuje do dbania o to, by zwiększony napływ środków publicznych był racjonalnie wydatkowany. Zgodnie ze współczesnymi „racjonalnymi mitami” (Meyer i Rowan, 1977), historycznie zmiennymi przekonaniami dotyczącymi tego, jak działają racjonalne struktury społeczne, kontrola ta przyjmuje formę quasi-rynkowego nadzoru za pomocą mechanizmów zaczerpniętych z teorii New Public Management (Stankiewicz, 2016a). To z kolei wywołuje (uzasadnioną) krytykę ze strony akademików, ponieważ efektem ubocznym nadzoru przy użyciu tych metod (zakładających konieczność stałych audytów, zamiast zaufania wobec profesjonalizmu pracowników drugiego sektora) jest znacząca rozbudowa aparatu biurokratycznego i obowiązków sprawozdawczych (Burawoy, 2013).

Trzeci czynnik motywujący państwo do ingerencji w system szkolnictwa wyższego jest kulturowy - nowe teorie rozwoju gospodarczego i związane z nimi plany Unii Europejskiej (sprzed okresu Wielkiej Recesji i późniejszego kryzysu strefy euro) uznawały gospodarkę wiedzy za główne źródło przyszłego wzrostu (Kok, 2004; Szwabowski, 2013). Skoncentrowana na „miękkich” kierunkach z zakresu nauk humanistycznych i społecznych struktura umasowionego szkolnictwa wyższego staje się, jeśli patrzeć z perspektywy tej teorii, patologią, którą należy poddać korekcie, ponieważ nie sprzyja ona rozwojowi 
przemysłu wiedzy. Wpływ na późniejsze fazy debaty mają też nowe (i do pewnego stopnia sprzeczne z teorią gospodarki wiedzy) dyskursy, jakie pojawiły się w wyniku długotrwałego kryzysu gospodarczego Zachodu, zwiększania się politycznej świadomości dotyczącej wzrostu w ostatnich trzech dekadach nierówności społecznych - niełagodzonych rozwojem tradycyjnie rozumianej gospodarki wiedzy (Piketty, 2014), i masowego bezrobocia młodych, na które receptą wydaje się raczej szkolenie zawodowe niż akademickie (Cahuc, Carcillo, Rinne i Zimmermann, 2013; Mourshed, Patel i Suder, 2014). Obie te rodziny proponowanych rozwiązań, za pośrednictwem transferu (nie zawsze adekwatnych do lokalnej sytuacji) dyskursów z krajów centrum na polskie półperyferia, bezpośrednio wpływają na politykę państwa, koncentrując uwagę tego ostatniego na systemie nauki i nauczania. Oba opisane powyżej nurty są uznawane za komplementarne - z perspektywy państwa konieczne wydaje się wzmocnienie zarówno systemu kształcenia w ramach nauk przyrodniczych i technicznych (ze względu na gospodarkę wiedzy), jak i odrodzenie szkół zawodowych (z powodu potencjału bezrobocia, jaki ma się wiązać z czysto akademickim szkoleniem w ramach miękkich dyscyplin) (Stankiewicz, 2016a). Brak adekwatności przedstawionych tu dyskursów wynika ze słabości polskiego przemysłu wysokich technologii i z gorszej od studentów masowych kierunków sytuacji zawodowej absolwentów nauk przyrodniczych i szkół czy studiów zawodowych (Hanushek, Woessmann i Zhang, 2011; Ministerstwo Nauki i Szkolnictwa Wyższego, 2016a, 2016b, 2016c). Dane empiryczne nie wydają się jednak znacząco osłabiać perswazyjnej siły oddziaływania zapożyczonych z krajów centrum dyskursów. Drugi czynnik kulturowy wiąże się z rosnącym znaczeniem międzynarodowych rankingów szkół wyższych (Szadkowski, 2015) i związanym z nim dążeniem wielu krajów do stworzenia „uniwersytetów o klasie światowej” (World-class universities, Hazelkorn, 2015; Shin i Kehm, 2012). Trudno o precyzyjne wyjaśnienie, jakie dokładnie negatywne konsekwencje ponosi Polska z tytułu słabej pozycji jej wiodących uniwersytetów w światowych rankingach - niemniej jednak, wskazywanie na ten fakt stanowiło i nadal stanowi legitymizację dla ingerencji w system nauki, a także dla jego dofinansowania.

Ostatnim czynnikiem motywującym państwo do działania jest konieczność odpowiadania na roszczenia jego najważniejszych publiczności - przedsiębiorców i klasy średniej.

Roszczenia klasy średniej wynikają z faktu, że wykształcenie wyższe w coraz większym stopniu determinuje społeczną pozycję, ścieżki kariery i zarobki należących do niej osób. O ile w czasach uniwersytetów elitarnych (pod koniec okresu komunistycznego uczęszczało do nich nie więcej niż 12\% kohorty) dyplom liceum wystarczał dla podjęcia pracy w większości zawo- 
dów wiążących się z pracą umysłową, o tyle współcześnie, w wyniku inflacji edukacyjnych kredencjałów, ukończenie szkoły wyższej może być wymagane nawet przy zatrudnieniu na znacznie mniej wymagających pozycjach (patrz: Kiersztyn, 2008, s. 260). Efekt ten wynika z komplementarnego wobec inflacji dyplomów zjawiska, które można nazwać edukacyjnym wyścigiem czerwonej królowej (Van Valen, 1973). Wartość edukacji jest pozycjonalna (Adnett i Davies, 2002; Frank, 1999; Hollis, 1982; Stankiewicz, 2014), to znaczy zależna nie tyle od „jakości” zdobytego przez nas dyplomu, co jego „jakości”, w porównaniu z dyplomami uzyskanymi przez naszych konkurentów na rynku pracy. Jeśli w wyniku umasowienia nasi konkurenci zdobędą dyplomy szkół wyższych, a my poprzestaniemy na dyplomie liceum, to nasza szansa na znalezienie zatrudnienia zmniejszy się. Fakt, że „trzeba biec tak szybko, jak się potrafi, żeby zostać w tym samym miejscu" (Carroll, 1972, s. 35), jest równoznaczny z rosnącymi wymaganiami edukacyjnymi wobec całego społeczeństwa i pojawieniem się, obejmującego klasę średnią, nieformalnego przymusu edukacyjnego dotyczącego edukacji trzeciego stopnia (Stankiewicz, 2015b).

Pojawiające się często, w należących do debaty nad szkolnictwem wyższym wypowiedziach, odniesienia do „nic niewartych dyplomów” (Hartman, Gawrońska, 2009) czy „śmieciowych absolwentów” (Kozłowski, 2012) są wobec tego raczej zaklinaniem rzeczywistości - przejawem niezgody na „degradującą" dla szkół wyższych konieczność prowadzenia masowych studiów czy upokorzenie wykształconej klasy średniej, zmuszonej do rywalizowania o swoją pozycję z edukacyjnymi nuworyszami - niż opisem empirycznej rzeczywistości. W rzeczywistości nawet najmniej prestiżowe dyplomy posiadają znaczną wartość pozycjonalną - odróżniając ich posiadaczy od wszystkich tych, którzy dyplomów nie zdobędą wcale. Co więcej, w społeczeństwach, w których połowa lub więcej kohorty zdobywa wykształcenie wyższe, brak dyplomu staje się czytelnym sygnałem braku ambicji lub kompetencji (Solga, 2002).

$\mathrm{Z}$ istnienia nieformalnego przymusu edukacyjnego wynikają dwa zestawy roszczeń ze strony przedstawicieli klasy średniej - po pierwsze, by wydające dyplomy szkoły w większym stopniu dbały o jakość nauczania, po drugie, by przeciwdziałać dalszej inflacji edukacyjnych kredencjałów. Pierwszy z tych elementów jest naturalną reakcją na pojawiające się od roku 2000 doniesienia prasowe, dotyczące niskiej jakości nauczania, i - tym razem od roku 2008 - te traktujące o nieprzydatności dyplomów na rynku pracy (te ostatnie są wynikiem ignorowania danych dotyczących, raczej niezłej, sytuacji absolwentów, patrz: Ministerstwo Nauki i Szkolnictwa Wyższego, 2016a, 2016b, 2016c). Druga grupa roszczeń - dotycząca zwiększenia prestiżu dyplomów, przejawia się w powszechnych wezwaniach do stworzenia w Polsce elitarnego 
sektora edukacji. Za jej element - ze względu na pozycjonalną naturę edukacji - można też uznać chęć ograniczenia umasowienia, zmniejszenia ilości wydawanych dyplomów magisterskich, dowartościowania licencjatów czy kształcenia zawodowego. Wszystkie te propozycje, choć wydają się dążyć do zwiększenia atrakcyjności innych form kształcenia niż „tradycyjne” studia magisterskie, w rzeczywistości, wypychając z uniwersytetów w przeważającej części tych, którzy najbardziej skorzystali na umasowieniu - przedstawicieli biedniejszych i słabiej wykształconych rodzin - zmniejszyłyby presję odczuwaną przez biorących udział w „wyścigu czerwonej królowej” tradycyjnych, pod względem przynależności klasowej, klientów uniwersytetów. Ponieważ wyścigi wszelakiego rodzaju są grą o sumie zerowej, więc przewagę w nich można zdobyć nie tylko biegnąć szybciej, ale też upewniając się, że nasi przeciwnicy będą poruszać się wolniej. Jak pisała autorka książki Does EducATION MATtER, Alison Wolf (2009), plany rewitalizacji szkolnictwa zawodowego, nawet jeśli przedstawia się je w dobrej wierze, zazwyczaj są tworzone przez osoby, które same zdobyły uniwersyteckie dyplomy i które nie wyobrażają sobie, by ich własne dzieci miały nie podążyć w ich ślady. Są to więc zawsze, tak samo w wypadku Wielkiej Brytanii jak i Polski, rozwiązania kierowane do „dzieci innych ludzi”, które ze względu na swoją klasową odmienność mają posiadać inne kulturowe czy ekonomiczne potrzeby i uzdolnienia.

Obie opisywane powyżej grupy roszczeń są związane z (przywoływanym w jednej z poprzednich sekcji) obiektywnym sukcesem uniwersytetów. Podobnie jak w krajach zachodnich, ich działalność zaczęła być postrzegana jako krytycznie istotna zarówno dla gospodarki, jak i większości społeczeństwa. Niestety, z większym społecznym wpływem wiąże się konieczność legitymizacji własnych działań przed znacznie bardziej zdeterminowanymi publicznościami, które w dodatku - w przypadku polskiej debaty - są z perspektywy lokalnej akademii bytami historycznie nowymi, niezwiązanymi wcześniej z uniwersytetem żadną "umową społeczną".

Możliwość pojawienia się takiej umowy, w formie, która mogłaby być zaakceptowana przynajmniej przez część akademików, zawiera się w roszczeniach, jakie wobec uniwersytetu przedstawiają sami jego pracownicy. Większość ich wypowiedzi stanowi świadectwo niechęci i niezrozumienia dla sytuacji, w której nauka i nauczanie nie są już uprawianymi dla siebie samych misjami, ale społecznymi funkcjami poddanymi zewnętrznemu nadzorowi. Z niezrozumieniem spotyka się też transformacja stawki społecznych gier, uzasadniających zdobywanie dyplomów. Nie jest nią już uzyskanie „kulturowego szlachectwa" i dołączenie do ożywianej dziejową misją dominującej warstwy społecznej, tylko zdobycie, często dość skromnej, przewagi w ry- 
walizacji o kapitał ekonomiczny. Niechęć ta wynika więc z istnienia „dyskursywnej luki”. Opiera się ona na próbie zrozumienia istniejących stanów społecznych za pomocą anachronicznych pojęć.

Punktem wspólnym roszczeń akademików i klasy średniej (szczególnie wyższej klasy średniej, posiadającej podobne aspiracje jak osoby wykształcone sprzed okresu umasowienia) jest możliwość przywrócenia uniwersytetowi prestiżu, przez powrót (przynajmniej w przypadku części placówek) do bezwzględnej selekcji - co skutkowałoby powstaniem dość jednorodnego, pod względem klasowym, ciała studenckiego.

Droga ku uniwersytetom elitarnym zaspokoiłaby roszczenia państwa (chcącego umieścić przynajmniej jedną placówkę wśród globalnej czołówki), wyższej klasy średniej (przez przywrócenie sprzyjających jej zasad edukacyjnego wyścigu) i akademików pragnących powrotu "dostojeństwa uniwersytetu”, a także ograniczenia do minimum kontaktów z klientami wymagającymi znacznego zaangażowania pedagogicznego. Propozycje koncentracji prestiżu w wybranych placówkach (i tym samym, zgodnie z zasadami gry o sumie zerowej, pozbawienia ich całej reszty) są - poczynając od roku 2008 - stałym elementem dyskursu publicznego. Taka umowa społeczna, pomiędzy wybranymi szkołami, państwem i dominującą warstwą społeczną, oznaczałaby oczywiście rezygnację z przypisywanej sobie tradycyjnie przez inteligencję (ale przed urynkowieniem sektora edukacji wyższej realizowaną w dość ograniczonym zakresie) misji „niesienia kaganka oświaty” masom. Dążenie do niej można jednak zrozumieć jako próbę uratowania misyjnego rdzenia akademii przed ingerencją zewnętrznych aktorów. Ostatecznym efektem trwającego właśnie okresu przemian będzie uniwersytet przynajmniej częściowo podporządkowany celom państwa i dominującej klasy społecznej. Stworzenie uczelni elitarnych można widzieć jako chęć przywrócenia utraconego autorytetu przynajmniej części akademii, pozostawiając (niemożliwą do uratowania) resztę na pastwę nowego, opartego na normach, regułach i rynkach, świata.

Ceną za tę zmianę musiałoby być pozbawienie wiodących uniwersytetów jakiejkolwiek funkcji emancypacyjnej i ponowne ścisłe ich związanie $\mathrm{z}$ władzami $z$ tego świata. Jest to rozwiązanie silnie zakorzenione $w$ tradycji akademii, zawsze stanowiącej pedagogiczne zaplecze dominujących społecznych instytucji i ukrywającej, dzięki temu, swoją niefunkcjonalną, z perspektywy większości populacji, misję przed nadzorem czy zarządzaniem. Wiązałby się z tym ostateczny kres pewnego snu - rezygnacja ze specyficznej dla Europy centralnej misji modernizacji i dołączenie klasy wykształconej do, pozbawionych społecznego wpływu i ambicji, globalnej wspólnoty sprofesjonalizowanych ekspertów. 


\section{BIBLIOGRAFIA}

Adnett, N., Davies, P. (2002). Education as a Positional Good: Implications for Market-Based Reforms of State Schooling. British Journal of Educational Studies, t. 50(2), s. 189-205.

Antonowicz, D., Godlewski, B. (2011). Demograficzne tsunami. Raport Instytutu Sokratesa na temat wplywu zmian demograficznych na szkolnictwo wyższe do 2020 roku. Warszawa: Instytut Sokratesa.

Antonowicz, D. (2015). Między siła globalnych procesów a lokalna tradycją: polskie szkolnictwo wyższe w dobie przemian. Toruń: Wydawnictwo Naukowe Uniwersytetu Mikołaja Kopernika.

Ashforth, B.E., Gibbs, B.W. (1990). The Double-edge of Organizational Legitimation. Organization Science, t. 1(2), s. 177-194.

Borowicz, R. (1983). Zakres i mechanizmy selekcji w szkolnictwie: kształtowanie się zbiorowości studentów. Warszawa: Państwowe Wydawictwo Naukowe.

Borowiec, M. (2011) Zmiany kierunków kształcenia akademickiego w Polsce. Prace Komisji Geografii Przemysłu Polskiego Towarzystwa Geograficznego, t. 18, s. 9-22.

Burawoy, M. (2013). Redefinicja publicznego uniwersytetu: ramy analityczne. Praktyka Teoretyczna, t. 7(1), s. 13-30.

Cahuc, P., Carcillo, S., Rinne, U., Zimmermann, K. F. (2013). Youth Unemployment in Old Europe: the Polar Cases of France and Germany. Journal of European Labor Studies, t. 2(1), S. $1-23$.

Carroll, L. (1972). O tym, co Alicja odkryła po drugiej stronie lustra. Warszawa: Czytelnik.

Cohen, A., Kisker, C. (2010). The shaping Of American Higher Education: Emergence and Growth of the Contemporary System (2nd ed.). San Francisco: Jossey-Bass.

Deephouse, D.L. (1996). Does isomorphism legitimate? Academy of Management Journal, t. 39(4), s. 1024-1039.

Duszak, A., Fairclough, N., (2008). Krytyczna analiza dyskursu: interdyscyplinarne podejście do komunikacji społecznej. Kraków: Universitas.

Fairclough, N. (2001). Language and Power. London: Addison-Wesley Longman.

Frank, R. (1999). Higher Education: The Ultimate Winner-Take-All Market? Pozyskano z: http://digitalcommons.ilr.cornell.edu/cheri/2/?utm_source=digitalcommons.ilr.cornell. edu\%2Fcheri\%2F2\&utm_medium=PDF\&utm_campaign=PDFCoverPages.

Geryk, M. (2007). Rynek uczelni niepublicznych w Polsce. Warszawa: Szkoła Główna Handlowa.

Etzkowitz, H., Webster, A., Gebhardt, C., Terra, B. R. C. (2000). The Future of the University and the University of the Future: Evolution of Ivory Tower to Entrepreneurial Paradigm. Research Policy, t. 29(2), s. 313-330.

Hanushek, E. A., Woessmann, L., Zhang, L. (2011). General Education, Vocational Education, and Labor-Market Outcomes over the Life-Cycle. National Bureau of Economic Research. Pozyskano z: http://www.nber.org/papers/w17504.

Hartman J., Gawrońska M. (2009). Dyplomy z zieleniaka, Newsweek, [online]. Pozyskano z: http://www.newsweek.pl/spoleczenstwo/dyplomy-z-zieleniaka,40617,1,1.html, [data dostępu: 12.01.2017].

Hazelkorn, E. (2015). Rankings and the Reshaping of Higher Education: The Battle for World-Class Excellence. New York: Palgrave Macmillan.

Hejnicka-Bezwińska, T. (2011). Próba odczytania strategii zmian w szkolnictwie wyższym (przeprowadzonych w ostatnim dwudziestoleciu). W: Kostkiewicz, J., Domagała-Kręcioch, A., Szymański, M. J. (red.), Szkoła wyższa w toku zmian. Debata wokół ustawy z dnia 18 marca 2011 roku (s. 11-20). Kraków: „Impuls”.

Herbst, M., Rok, J. (2011). Equity of Access to Higher Education in the Transforming Economy. Evidence from Poland. Investigaciones de Economía de la Educación, t. 6, s. 475-494.

Hollis, M. (1982). Education as a Positional Good. Journal of Philosophy of Education, t. 16(2), s. $235-244$. 
Jessop, B. (2002). The Future of the Capitalist State. Cambridge: Polity Press.

Karabel, J. (2005). The Chosen: The Hidden History of Admission and Exclusion at Harvard, Yale, and Princeton. Boston: Houghton Mifflin Harcourt.

Keynes, J. M. (2003). Ogólna teoria zatrudnienia procentu i pieniądza. Warszawa: Państwowe Wydawnictwo Naukowe.

Kiersztyn, A. (2008). Czy bieda czyni złodzieja?: związki między bezrobociem, ubóstwem a przestępczością. Warszawa: Wydawnictwo Uniwersytetu Warszawskiego.

Kobylarek, A. (2013). Osiaganie konsensusu interesariuszy edukacji akademickiej. O społecznej misji uniwersytetu. W: Czerepaniak-Walczak, M. (red.), Fabryki dyplomów czy universitas? (s. 108-130). Kraków: „Impuls”.

Kok, W. (2004). Facing the Challenge: The Lisbon Strategy for Growth and Employment. Luxembourg: Office for Official Publications of the European Communities. Pozyskano z: http:// dspace.ceu.es/handle/10637/2481.

Kozłowski T. (2012). Dialog w fabrykach bezrobotnych. Gazeta Wyborcza, [online]. Pozyskano z: http://wyborcza.pl/1,95891, 11645483,Dialog_w_fabrykach_ bezrobotnych.html, [data dostępu: 12.01.2017].

Kwiek, M. (2009). The Two Decades of Privatization in Polish Higher Education. Cost-sharing, Equity, and Access. W: Knight, J. (red.), Financing Access and Equity in Higher Education (s. 149-167). Papendrecht: Sense Publishers.

Kwiek, M. (2010). Transformacje uniwersytetu: zmiany instytucjonalne i ewolucje polityki edukacyjnej w Europie. Poznań: Wydawnictwo Naukowe Uniwersytetu im. Adama Mickiewicza.

Kwiek, M. (2012). Changing Higher Education Policies: From the Deinstitutionalization to the Reinstitutionalization of the Research Mission in Polish Universities. Science and Public Policy, t. 39(5), s. 641-654.

Kwiek, M. (2013). From System Expansion to System Contraction: Access to Higher Education in Poland. Comparative Education Review, t. 57(3), s. 553-576.

Kwiek, M. (2015). Uniwersytet w dobie przemian. Warszawa: PWN.

Latour, B., (2010). Splatajac na nowo to, co społeczne: wprowadzenie do teorii aktora-sieci. Kraków: Universitas.

Meyer, J. W., Rowan, B. (1977). Institutionalized Organizations: Formal Structure as Myth and Ceremony. American Journal of Sociology, t. 83(2), s. 340-363.

Ministerstwo Nauki i Szkolnictwa Wyższego (2016a). Ekonomiczne aspekty losu absolwentów. Poziom ogólnokrajowy. Studia Pierwszego Stopnia, [pdf]. Warszawa: Ministerstwo Nauki i Szkolnictwa Wyższego. Pozyskano z: http://absolwenci.nauka.gov.pl/reports/PL_1_stopnia.pdf.

Ministerstwo Nauki i Szkolnictwa Wyższego (2016b). Ekonomiczne aspekty losu absolwentów. Poziom ogólnokrajowy. Studia Drugiego Stopnia, [pdf]. Warszawa: Ministerstwo Nauki i Szkolnictwa Wyższego. Pozyskano z: http://absolwenci.nauka.gov.pl/reports/PL_2_stopnia.pdf.

Ministerstwo Nauki i Szkolnictwa Wyższego (2016c). Ekonomiczne aspekty losu absolwentów. Poziom ogólnokrajowy. Studia Jednolite, [pdf]. Warszawa: Ministerstwo Nauki i Szkolnictwa Wyższego. Pozyskano z: http://absolwenci.nauka.gov.pl/reports/PL_jednolite_mgr. pdf.

Mourshed, M., Patel, J., Suder, K. (2014). Education to Employment: Getting Europe's Youth into Work, [pdf]. McKinsey Company. Pozyskano z: http://economicgrowthdc.org/work/ assets/McKinsey-Education-to-Employment-Europe.pdf.

Piketty, T. (2014). Capital in the Twenty-First Century. Cambridge: Harvard University Press.

Shin, J. C., Kehm, B. M. (2012). Institutionalization of World-Class University in Global Competition. New York: Springer.

Solga, H. (2002). Stigmatization by Negative Selection: Explaining Less-Educated People's Decreasing Employment Opportunities. European Sociological Review, t. 18(2), s. 159-178. 
Stankiewicz, Ł. (2014). Spór o edukację wyższą w perspektywie teorii dóbr pozycjonalnych. Teraźniejszość - Człowiek - Edukacja, t. 66(2), s. 109-130.

Stankiewicz, Ł. (2015a). Społeczna wiedza i legitymizacja a przemiany polskiego uniwersytetu. Nauka i Szkolnictwo Wyższe, t. 2(46), s. 139-160.

Stankiewicz, Ł. (2015b). Pułapka umasowienia - o sprawczości jednostek w umasowionym systemie szkolnictwa wyższego. Nauka i Szkolnictwo Wyższe, t. 1(45), s. 191-213.

Stankiewicz, Ł. (2016a). Wizje uniwersytetu w polskiej debacie publicznej 2007-2010. Kraków: „Impuls”. W redakcji.

Stankiewicz, Ł. (2016b). Krytyka umasowienia szkolnictwa wyższego w Polsce i Stanach Zjednoczonych - analiza dyskursu mediów masowych. W redakcji.

Suchman, M. C. (1995). Managing Legitimacy: Strategic and Institutional Approaches. The Academy of Management Review, t. 20(3), s. 571-610.

Szadkowski, K. (2015). Uniwersytet jako dobro wspólne: podstawy krytycznych badań nad szkolnictwem wyższym. Warszawa: Wydawnictwo Naukowe PWN.

Szwabowski, O. (2013) Neoliberalna restrukturyzacja fabryki edukacyjnej. W: Czerepaniak-Walczak, M. (red.), Fabryki dyplomów czy universitas? (s. 79-107). Kraków: „Impuls”.

Valen, Van, L. (1973). A New Evolutionary Law. Evolutionary Theory, t. 1, s. 1-30.

Wolf, A. (2009). Does education matter? Myths about education and economic growth. Kindle Edition.

Wolszczak-Derlacz, J., Parteka, A. (2010). Produktywność naukowa wyższych szkół publicznych w Polsce. Bibliometryczna analiza porównawcza. Warszawa: Ernst\&Young.

\section{SUMMARY}

\section{Polish public debate and academy disenchantment -about changes in public perception of the university in the last three decades (Part I)}

Polish university has been recently a subject of much public controversy. The debate concerning the 2011 reforms of the higher education and science sector still continues-changing the way, in which both the academics and the general public think and speak about the university.

The purpose of this paper is the analysis of the critical media discourses concerning the academic world during the last three post -1989 decades. The analysis is based on prior research and uses institutional theory of organization as an interpretative framework. Within this framework the current situation of the higher education and science sector can be interpreted as a legitimation crisis, brought about by the interlocking changes in demographics, the mode of financing, the relationships between universities, the state and other social actors, as well as the relationships of actors participating in the sector. The summary effect of this changes is the transfer of universities from the sphere of organizations that base their legitimacy on authority to the technical sphere-operating on the basis of rational calculation concerning the utility of their products and services. This change is at odds with the humanist discourse on the university, but it also has many historic precedents and expresses the growing importance of academic activities in both educational and knowledge-creation dimension.

KEY WORDS: higher education, discourse, public debate. 